\title{
DOUBLE PERSPECTIVE IN TWO WORKS OF JORGE AMADO
}

\author{
Bobby J. Chamberlain
}

I. The greater degree of ironic detachment with which Jorge Amado has approached action and characters in much of his latter-day fiction has been most pronounced in the works that emphasize the relativity of truth. Nowhere is this more apparent than in the two novelettes of Os Velhos Marinheiros. ${ }^{1}$ Both "A Morte e a Morte de Quincas Berro D'água" and "A Completa Verdade sobre as Discutidas Aventuras do Comandante Vasco Moscoso de Aragão, Capitão de Longo Curso" deliberately leave the reader with considerable doubt as to the reality/irreality of the events they narrate. This they achieve primarily through the use of such ironic devices as multiple narrators, unreliable narrators, contrapuntal internal reduplications and double perspective. ${ }^{2}$ Of these, the last-named has perhaps received the least attention. I should like to examine it briefly here in order to establish some of its types and functions within Amadian fiction, laying special emphasis on its sociological ramifications. But first a word is in order about the general nature of double perspective as seen by several prominent literary critics. Their views will serve as a grid against which to assess the role of double perspective in the present works.

II. Double perspective is commonly known by various names: "dual focus," "binary characterization" and "bipolar narration," to list a few. But, whatever the term employed, it does not appear to have a large critical bibliography of its own. Indeed, one is often obliged to consult such topics as "irony" and "ambiguity" in order to find the slightest mention of the technique. Northrop Frye makes one such mention in his discussion of mythoi, or archetypal plot formulas. He detects in the quest phase of tragedy an ironic undercurrent of victory within disaster, often revealed by a double perspective in the action. By way of example, he cites Milton's Samson Agonistes, in which "Samson is a buffoon of a Philistine carnival and simultaneously a tragic hero to the Israelites, but the tragedy ends in triumph and the carnival in catastrophe."3

In his recent book entitled $A$ Rhetoric of Irony, Wayne C. Booth provides additional insights. He differentiates deliberate ambiguity produced by a "doubled vision" from what he calls "stable irony," noting that the former defies univocal interpretation while the latter demands it. Furthermore, he adds, where there is a doubled vision "neither perspective is ever as fully realized in itself as it might have been without the constraints of the other." 4 In support of this contention, he recalls the perceptual problems created by optical illusions, such as those made famous by Wittgenstein and Gombrich and those seen throughout the art of M. C. Escher. ${ }^{5}$ 
A third view of double perspective is that of Sharon Spencer, who in her study Space, Time and Structure in the Modern Novel observes that the creation of two conflicting viewpoints within a single text often forces the reader to reconcile the discrepancies by inventing a third, synthetic perspective. Thus, while the two versions of truth may seem to cancel each other out, they may actually cohere at a higher level. ${ }^{6}$

Finally, a fourth approach may be inferred from some of the remarks Roland Barthes has addressed to the topic of ambiguity. He discerns in every work of fiction a series of dilatory devices used to create and maintain suspense, of which the equivoque or double meaning is among the most important. Dubbing this phenomenon the "hermeneutic code," he notes that its primary function is to delay the resolution of the various enigmas posed by the text. But, the code may also be viewed in its own right as a type of "countercommunication." Thus, in Barthes' opinion, the equivoque is more than just a means of interfering with the univocality of the text; it has meaning in and of itself. ${ }^{7}$ Double perspective, insofar as it is ambiguous, may be said to fulfill a similar role.

To sum up, then, double perspective, as seen by the critics, is often associated with the irony of victory within tragedy, with ambiguous, mutually inhibiting points of view and with an implicit third perspective, which the reader is called upon to synthesize. Moreover, if we may be permitted to extrapolate, it conveys its own inherent meaning, independent of the two countervailing meanings that it holds in equilibrium.

III. Double perspective is for all intents and purposes first employed by Amado in "Quincas." In addition to highlighting the subjectivity of conflicting versions of truth, it serves to comically underscore existing differences in class values and priorities. The petit-bourgeois family of the late, lamented Joaquim Soares da Cunha, alias Quincas Berro D'água, considers his autumnal sowing of wild oats to be an embarrassment, his life having ended for them the day of this abrupt departure from "polite society" several years earlier. When confronted with the fait accompli of his actual death, they are only too hapyy to lay him to rest with as little fanfare and expense as possible and without any further humiliation for themselves. To his skidrow companions - and to Quincas himself - however, his life only began when at the age of fifty he abandoned wife and family, thus repudiating the drab reality of Joaquim Soares da Cunha. His belated devotion to a liberated existence has elevated him in their eyes to the status of a folk hero. And with his passing their lives have been impoverished.

Joaquim-Quincas is thus endowed with a dual identity - one for each social class. Indeed, much of the ironic humor and social satire of the work stems from the direct confrontation of these two diametrically opposite points of view - the one more materialistic, the other more spiritual. While the early and final chapters deal separately with the reactions of both parties, one of the later episodes - the wake scene juxtaposes the two "families" and their conflicting social values, as if to represent a symbolic enactment of the class struggle. Decked out in the garb of a bom burgues, Quincas is barely recognizable to his humble associates (p. 48). To Vanda, his daughter, Joaquim in death had seemed finally to submit to her iron will and, by extension, to that of her dead mother, whom he had abandoned. She had at last succeeded in erasing his defiant smile; no longer did she "imagine" hearing his earthy expletives arising from the open coffin. But, with the arrival of the four "vagrants," he seems to have regained his 
stubborn rebelliousness, the contemptuous smirk on his lifeless face having strangely reappeared (p. 49).

The full force of Amado's biangular portrayal of Joaquim-Quincas is not felt, however, until after the withdrawal of the Cunha family from the wake. The focus now shifts away from the conflicting social ethics implicit in the dual identity to the very question of whether Joaquim-Quincas is actually dead - as had been presumed - or merely "playing possum" to humiliate his snobbish relatives. The reality of his every "action" and "reaction" is thus rendered ambiguous by the novelist. This is accomplished in part by the narrator's repeated use of such expressions as parecia, pelo jeito and evidentemente to qualify the description of the "decedent"'s apparent attitudes and feelings.

The several utterances ascribed to Berro D'água toward the end of the wake, though if true plainly indicate that he is still alive, may also be interpreted as hallucinations induced by the convenient drunkenness of the four remaining mourners. Yet, it is never completely clear which of these interpretations the reader is expected to accept. An additional quantum of ambiguity is generated by the narrator's use of double-entendres and his description of Quincas' movements with verbs that connote voluntary action. Thus, during the drunken romp toward the waterfront to which the four companions drag the would-be corpse, Quincas is equivocally described as being "satisfeito da vida" (p. 59), "num dos seus melhores dias" (p. 60) and "no melhor de sua forma" (p. 63). It is further noted that "Quincas quase corria, tropeçava nas pedras" ( $\mathrm{p}$ 62), that at one point he tried to trip his comrades while sticking his tongue out at passers-by (p. 60), and that finally "Quincas se pôs de pé" (p. 65) before "diving" into the sea. Thus, the ambiguity is gleefully maintained.

Perhaps the major bone of contention to separate the dichotomous views of Joaquim-Quincas is the manner, time and place of his extinction. Although the narrator sets out to unravel the mystery, in the end the decision as to where the truth lies is clearly left up to the reader. If, as the Cunha family contends, the demented patriarch expired quietly in a filthy cubicle on the Ladeira do Tabuão, than logically the account of those who claim to have seen Quincas plunge into the surf of All Saints' Bay of his own free will is but a canard concocted by a band of drunken miscreants. If, on the other hand, Quincas was still alive throughout the wake and subsequently joined his comrades for a final fling before taking his own life in the waves, then it is safe to surmise that the entire "death scenario" was merely an elaborate scheme to have the last laugh on his haughty kin. The only other alternative - death and resurrection - is at once the least logically possible and the most symbolically satisfying. ${ }^{8}$ For, if we admit the possibility of Quincas' magically transcending death to preserve his cherished freedom, then we have already gone a long way toward invalidating the kinds of hypocrisy and petty materialism that so provoked his angry rebellion. Yet again we are never told which one of these realities to accept; the narrative remains open-ended.

In any event, both the hero's twofold identity and the amusing controversy surrounding his death serve primarily to set forth in a non-threatening, seemingly disinterested fashion the fundamental economic divergences that underlie the two contradictory ethoi in question. Thus, by employing a double perspective, the author 
succeeds in effectively conveying his ideological message while also managing to entertain his readership.

IV. A second, and equally artistic, form of double perspective emerges in "Comandante." Vasco is seen by his retinue of admirers as a swashbuckling hero of the seven seas; he is drawn by his detractors as a grocery heir and flagrant hoaxer. Vested interests motivate the positions of both parties. The former seek to preserve in Vasco what they feel to be their own just parcel of greatness, while the latter endeavor to aggrandize themselves by exposing the "master mariner" as a phony.

Vasco, however, is not the only one in the story to receive a binary characterization. Depending on which version of the Comandante's life is believed, Johann is either a Swedish sailor (p. 97) or a Swedish tobacco exporter (p. 158); Soraia, an exotic Arab dancer (p. 97) or a Brazilian dance-hall girl (p. 158); Menendez, an ill-tempered shipowner (p. 99) or a heartless food wholesaler (p. 148); Giovanni, an Italian seaman (p. 98) or an elderly black stockroom employee (p. 151); and Robert or Roberto, a rich, abdominous Britisher (p. 107) or a wealthy Bahian playboy (p. 143).

Two characters, Carol and Dorothy, are supplied with at least three personalities apiece. By one of Vasco's accounts, Carol is an opium smuggler in the East Indian seaport of Makassar (p. 106), while in another she is represented as Sister Carol, a devout Asian missionary (p. 290). Yet, according to Chico Pacheco, she is in reality the proprietress of a noted Salvador brothel (p. 141). Again, if one can place any trust in the Captain's tales, Dorothy, a passenger on one of the many ships under his command, succumbed to yellow fever after renouncing both husband and fortune to spend her life with the seafaring hero (pp. 105-07, 289-90). If, on the other hand, Chico is telling the truth, Dorothy is a kept woman kidnapped by Vasco's friends in Bahia so that she and Vasco may be able to carry on a passionate love affair (pp. 143, 174-80). Still a third alternative, appearing in one of Vasco's alleged dreams of grandeur, pictures Dorothy as the alluring spouse of the Bahian Secretary of Transportation, who has come to dedicate a rail line constructed by the renowned "Doutor Vasco Moscoso de Aragão, engenheiro civil" (p. 166).

Despite the double perspective of "Quincas," the decedent's two identities are not presented as mutually exclusive realities, but as successive periods in his life. The only real dispute over the objective truth, then, centers on the circumstances of his untimely death. Barring some sort of miraculous resurrection, one must choose one account or the other, or else provide a viable compromise. With Vasco, however, each version of his past existence seemingly precludes the other. He is either a seasoned sea dog or a posturing landlubber - but not both.

Or so it seems, at least, until he is called upon to take command of a captainless ship bound for Recife and points north. Oddly enough, throughout this "initiation ordeal" the two realities appear juxtaposed in Vasco's thoughts and statements, as though they formed a harmonious continuum. He is at once the Aragãozinho of grocery fame and the intrepid conquer or of the briny deep, a frequenter of Salvador's Pensão Monte Carlo and a habitué of Oriental cabarets, an acquaintance of the Bahian Governor and an on-the-spot defender of the Portuguese Crown (pp. 231, 236, 247, 250, 252, 283, 292). Not satisfied with only two antithetical options with which to mislead his reading 
audience, the novelist thus has further clouded the picture by mischievously hinting at a third, hybrid thesis, which seems to raise as many questions as it purports to settle.

It might be argued that one convenient way to represent the resulting structure of "Comandante" would be in the tripartite schema of thesis $>$ antithesis $>$ synthesis. ${ }^{9}$ Yet, this is true only to a limited degree. For, although there occurs in the end an interpenetration of thesis and antithesis, the very fact that this is done primarily to further confuse the reader means that the synthesis must remain only partially actualized. Only the least controversial elements of the conflicting first and second perspectives are homogenized to form the third. There is never any attempt to explain away the sharpest points of disagreement, for they cannot be explained away.

Thus, like "Quincas," "Comandante" is in the final analysis essentially open-ended. And this open-endedness results not so much from the creation of multiple overlapping truths as it does from the interplay of two diametrically opposite points of view.

V. Turning now to the applicability of the views expressed by the above-named literary critics, we are also in a position to gauge how the alleged characteristics may relate to the novelist's overall sociological purpose in the two works in question. As to Frye's observation that double perspective of ten houses the irony of triumph within catastrophe, it appears to pertain to some degree in both cases. Quincas turns defeat into victory if indeed he does transcend death to reclaim his precious individualism. Vasco too in the end manages to overcome certain vanquishment at the hands of the narrowminded, though not without aid from supernatural forces (i.e., the deus ex machina of a destructive wind and rain storm). But, in both works, the fact that the hero is unexpectedly able to prevail despite impending disaster eventually assumes greater importance than the very question of where the truth lies. Thus, it may be contended with some validity that Amado uses the double perspective less as a rhetorical discovery procedure than as a means of maintaining the pretense of neutrality while actually enhancing the effect of his own parti pris. He is less concerned with the details of a particular event or character's life than with the subjacent social values on which we base our perceptions of those details. And he clearly displays a preference for one set of social values over the other.

The relevance of Booth's claims appears to be mixed. On the one hand, his association of "doubled vision" with ambiguity seems to ignore the non-mutuallyexclusive type of dual focus, such as that which centers on Quincas' dual identity. On the other hand, given this limitation, his contention that both perspectives will necessarily be flawed by the need to interlock with one another seems to be borne out by the remaining two cases. Taken alone, neither of the two strictly realistic alternatives for explaining the disappearance of Quincas' body is free of internal contradictions. Each has had to sacrifice something to achieve the illusion that both are plausible. If we accept the version of those who claim that the body was stolen, are we then to dismiss as hallucinations or lies the various words and actions attributed to the would-be decedent even before his companions' arrival? If we are convinced that Quincas was simply playing a practical joke, how can we account for the undertaker's apparent failure to detect this? Much the same is true of "Comandante." For, as we have seen, the author's attempt to reconcile 
the opposing versions in a third, mixed perspective is at best half-hearted and stops well short of smoothing all the rough edges. And this would appear to be as much the result of the internal inconsistencies of each perspective as it is of the fundamental divergences between the two perspectives.

As regards Spencer's findings, they too are most applicable where ambiguity is involved. There is no pressure on the reader to forge a compromise reality from the two identities of Quincas, for they are diachronic - not synchronic - in nature. Nor does one preclude the validity of the other. Yet, in the case of Quincas' death, quite the contrary is true. Inherent in the open-endedness of the opposition is a demand for resolution in a third perspective, provided one does not opt for one of the first two. It is the reader who must supply this synthesis. "Comandante" is a bit more complicated. It would appear on the surface that Amado, seeing the need for a third, conciliatory perspective, has anticipated the reader by meshing the two realities in the final section of the novelette. Thus, the synthesis would appear to be more explicit than implicit. But, as we have seen, the existence of a true third perspective is more illusory than real. Hence, a continuing need for the reader to perform the synthesizing operation.

Barthes' comments lend additional focus to the preceding views. We have noted that in using a double perspective as a vehicle to convey the irony of victory within disaster Amado is actually violating his supposed neutrality. Further, we have observed that the equivocal presentations of Quincas' death and Vasco's identity are based on mutually inhibiting binary perspectives. And, finally, we have seen that in both works the contradictions between thesis and antithesis tacitly encourage the construction of a synthesis. In light of Barthes' assertion that there is a deliberate meaning, or countercommunication, in the very equivocality of an equivocal statement, it is not unreasonable to regard the above characteristics as integral components of the author's message.

Thus, on the one hand, Amado appears to be calling attention to the futility of trying to recover the truth from either of the two conflicting perspectives. For both contain serious internal inconsistencies. On the other hand, he seems to be suggesting that even the reconciliation of the two into a cohesive synthesis may be difficult - at least if we expect to eliminate all points of disagreement. For, as in the Hegelian dialectic, any such synthesis will itself necessarily become another thesis with its own innate contradictions and need for resolution in another synthesis. What is more, no two syntheses will be exactly alike. Faced with the open-endedness of the two tales, every reader will attempt to reconcile the incongruities in a third perspective. But, in the end, even this perspective will prove to be partial, to the extent that it is influenced by his/her personal biases. Thus, every reader in effect will create his/her own version of the truth.

VI. The sociological implications are not difficult to draw. By associating the conflicting perspectives in the two works with opposing social classes or community ethics, Amado seeks to show that no single class or ethic is capable of unilaterally satisfying human needs. Difficult though it may be to attain, only a synthesis of some sort can provide a workable solution for society's problems. And no two solutions will be identical. Each will inevitably be influenced by the pre-existing tendencies and partialities of the society in question. 
Amado's ultimate solutions for the two tales do little to resolve the factual contradictions raised by the double perspectives. Quincas' hinted resurrection and Vasco's heaven-sent storm are in the final analysis nothing more than wish fulfillments used to implement the author's notions of poetic justice. The question of what is real and what is unreal is left for the reader to determine.

Thus, the use of double perspective, while allowing the author greater latitude to ironize his characters, does not prevent him from displaying his partisanship. He reserves the right to create and take sides in parallel double perspectives and to resolve ambiguities by imposing his own will. Having explored the diverse facets of truth, he acknowledges it relativity, but shows this relativity to be socially conditioned. Double perspective thus serves him as a means of translating the various moral and social cleavages into discrepancies of opinion and perception. Yet, because of its seeming dispassion, it also affords him the luxury of weaving his own whimsical truth while still preserving a thin veil of impartiality.

Department of Romance and Classical Languages
Michigan State University - USA

\section{REFERENCES}

1 Jorge Amado, Os Velhos Marinheiros: Duas Histórias do Cais da Bahia (São Paulo: Martins, 1961). This volume contains the two novelettes, "A Morte e a Morte de Quincas Berro D'água" and "A Completa Verdade sobre as Discutidas Aventuras do Comandante Vasco Moscoso de Aragão, Capitão de Longo Curso." "Quincas" first appeared in the magazine Senhor 1 (1959), 50-66. Citations from "Quincas" and "Comandante" will be taken from the seventeenth edition of Os Velhos Marinheiros (São Paulo: Martins, 1967). Page numbers will be supplied parenthet ically within the text. Another form of double perspective may be witnessed in Amado's Tenda dos Milagres (São Paulo: Martins, 1969). A discussion of Tenda is regrettably beyond the purview of this study.

${ }^{2}$ An alternative way of treating double perspective might be to regard it within the context of internal reduplication. I shall not employ this approach in the present essay.

${ }^{3}$ Northrop Frye, Anatomy of Criticism: Four Essays (Princeton: Princeton Univ. Press, 1957), pp. 220-21.

${ }^{4}$ Wayne C. Booth, A Rhetoric of Irony (Chicago: Univ. of Chicago Press, 1974), p. 128, n. 15.

${ }^{5}$ Ibid., pp. 127-28.

${ }^{6}$ Sharon Spencer, Space, Time and Structure in the Modern Novel (Chicago: Swallow Press, [1974]), p. 88 .

${ }^{7}$ Roland Barthes, S/Z, trans. Richard Miller (New York: Hill and Wang, 1974), pp. 75-76, 144-45. Other devices of the hermeneutic code include the "snare" (or red herring), the partial ansiver, the suspended answer and "jamming (acknowledgment of insolubility)" (pp. 75-76). 
${ }^{8}$ With the resurrection alternative, intertextuality also comes into play. Indeed, one critic, Elizabeth Schlomann Lowe, observes that “a bizarre parallel can be drawn between Quincas' first death, his spiritual reincarnation (which is implemented by his friends), and his second death, with the death and resurrection of Christ" ("The 'New' Jorge Amado," Luso-Brazilian Review, 6, No. 2, Dec, $1969,79)$.

${ }^{9}$ Whether by design or not, the Hegelian dialectic appears to be the organizing principle for several other Amadian works, including Gabriela, Cravo e Canela: Crônica de uma Cidade do Interior (São Paulo: Martins, 1958) and Dona Flor e Seus Dois Maridos: História Moral e de Amor (São Paulo: Martins, 1966). 